ZOOLOGIA 27 (6): 965-972, December, 2010

doi: $10.1590 /$ S1984-46702010000600019

\title{
Offspring production in three freshwater crab species (Brachyura: Pseudothelphusidae) from the Amazon region and Central America
}

\author{
Ingo S. Wehrtmann ${ }^{1,5}$; Célio Magalhães²; Patricio Hernáez ${ }^{1,3,4}$ \& Fernando L. Mantelatto ${ }^{4}$ \\ ${ }^{1}$ Unidad de Investigación Pesquera y Acuicultura of the Centro de Investigación en Ciencias del Mar y Limnología, \\ Universidad de Costa Rica. 2060 San José, Costa Rica.E-mail: ingowehrtmann@gmx.de \\ 2 Coordenação de Pesquisas em Biologia Aquática, Instituto Nacional de Pesquisa da Amazônia. Caixa Postal 487, \\ 69011-970 Manaus, AM, Brazil. E-mail: celiomag@inpa.gov.br \\ ${ }_{3}^{3}$ Museo del Mar, Universidad Arturo Prat. Casilla 121, Iquique, Chile. E-mail: phernaez@lycos.com \\ ${ }^{4}$ Laboratório de Bioecologia e Sistemática de Crustáceos, Departamento de Biologia, Faculdade de Filosofia, Ciências e Letras \\ de Ribeirão Preto, Universidade de São Paulo, Programa de Pós-Graduação em Biologia Comparada. Avenida Bandeirantes \\ 3900, 14040-901 Ribeirão Preto, SP, Brazil. E-mail: flmantel@usp.br \\ ${ }^{5}$ Corresponding author. E-mail: ingowehrtmann@gmx.de
}

\begin{abstract}
Freshwater crabs are an important component of the fauna of limnic environments, and out of the two true freshwater crab families present in the Neotropics, Pseudothelphusidae is the most diverse. Considering the lack of information regarding reproductive features of neotropical freshwater crabs, we studied, for the first time, the fecundity and the presence of juveniles carried by females of two pseudothelphusids from the Amazon region - Kingsleya latifrons (Randall, 1840) and Kingsleya ytupora Magalhães, 1986 - and one from Central America - Potamocarcinus magnus (Rathbun, 1896). The two Kingsleya species produced relatively few (56-114) and large eggs (1.9-3.7 mm), typical for species with an abbreviated or direct development. Recently produced eggs were substantially larger in $K$. latifrons (mean $2.83 \mathrm{~mm}$ ) when compared to those of $K$. ytupora (mean $1.87 \mathrm{~mm}$ ); however, at the end of the embryogenesis, mean egg diameter was similar in both species. Therefore, it is assumed that hatchlings in both species should have a similar size. A brief description of attached juveniles of $K$. ytupora is provided. The number of juveniles varied between 30 (K. ytupora) and 179 (P. magnus); two size groups of juveniles were found, which indicates that the offspring cling to their mother for a prolonged period of time. There was no significant loss of eggs and juveniles; it is assumed that parental care diminishes the loss of their offspring. We compiled the available information of reproductive aspects from freshwater crabs: egg diameter was in the range of 2-3 mm, independent of female size and fecundity, and reported egg number varied between 9 and 417 eggs.
\end{abstract}

KEY WORDS. Brazil; Costa Rica; freshwater crabs; direct development; fecundity; parental care.

The Pseudothelphusidae, with over 250 valid species (NG et al. 2008, Yєo et al. 2008), is by far the most diverse of the two true freshwater crab families from the Neotropics. Their representatives are distributed from northern Mexico to Central and South America as far as the southern limits of the Amazon Basin, and have been reported also from some of the Caribbean islands (Rodríguez 1982). Most of the South American species inhabit mountainous areas along the Andes, but a branch of the Kingsleyini, represented mainly by the genera Fredius Pretzmann, 1967, Microthelphusa Pretzmann, 1968, and Kingsleya Ortmann, 1897 extend to the Guyana Shield and Amazon Basin (RoDríGuez 1982).

RodrígueZ \& MAgALHÃES (2005) summarized the available information on the Pseudothelphusidae and, for Central America, indicated the presence of 13 genera including 43 species. Similarly, MAGALHÃEs (2003a) provided a list of five genera and nine species for Brazil. In spite its high diversity (Yeо et al. 2008), the biological and ecological aspects of these pseudothelphusid freshwater crabs are poorly studied. Except for a few brief ecological notes (Rodríguez \& MagalHães 2005), the majority of the publications on the neotropical families deal with systematics, taxonomy or zoogeography. However, to the best of our knowledge, reproductive features of neotropical pseudothelphusids are completely unknown.

All seven species currently assigned to Kingsleya have their distribution associated to the uplands of the Guyana and the Central Brazilian Shields (MagalHães \& TÜrkay 2008). The species are usually known only from their type material and eventually from a few additional specimens. Exceptions are Kingsleya latifrons (Randall, 1840) and Kingsleya ytupora Magalhães, 1986 for which some scattered observations of females with eggs and newly-hatched juveniles have been mentioned by MAGA- 
LHÃES $(1986,2003 b)$. These species are typically found in fastflowing habitats such as rapids and waterfalls, occurring among fissures, or under submerged rocks in shallow waters or occasionally out of the water, but always in the close vicinity of the water source (MAGALHÃES 1986, 2003b). No information on the reproductive cycle for these species is available, except for the observations from MaGalHães (1986) who indicated that females of $K$. latifrons carrying eggs or young were captured in July and September (Rio Uatumã) and in October (Rio Trombetas) in the northern tributaries of the Amazon River. For K. ytupora, egg-bearing females were also reported in October among material collected in the Rio Xingu (Magalhães 2003b). The embryonic or postembryonic development has not been described for any of the Kingsleya species, and the same is true for the species of Potamocarcinus H. Milne Edwards, 1853 from Central America.

Considering the almost complete lack of information regarding the reproductive features of neotropical freshwater crabs, the present study aimed to offer data about fecundity and the presence of juveniles carried by females of two pseudothelphusid crab species from the Amazon region ( $K$. latifrons, K. ytupora) and one from Central America Potamocarcinus magnus (Rathbun, 1896). The results obtained are part of a long-term collaborative project on freshwater crabs of Central and South America to provide insights in the reproductive strategies of freshwater decapods and will hopefully stimulate more studies on the ecology of these poorly known representatives of the neotropical freshwater fauna.

\section{MATERIAL AND METHODS}

Ovigerous females and females carrying juveniles were obtained from the collections of the Instituto Nacional de Pesquisas da Amazônia (INPA), Manaus, Brazil and of the Museo de Zoología (UCR-MZ), Escuela de Biología, Universidad de Costa Rica, San José, Costa Rica. These two collections contain the largest holdings of Pseudothelphusidae in their respective geographic areas. In the INPA-collection, a total of 38 lots of $K$. latifrons and K. ytupora were checked for the presence of females bearing eggs or juveniles. In some of the lots females with egg/ juveniles were not kept separately, but these vials were inspected carefully for eggs/juveniles, which may have detached from the females. Therefore, detached eggs/juveniles were taken into consideration for their count. In the entire collection of the UCRMZ, comprised by 218 lots of Pseudothelphusidae, only one female of P. magnus was found with attached juveniles. Additionally, abundant material recently collected by Rólier Lara (Instituto Costarricense de Electricidad, Costa Rica) in the Pacific lowlands of southern Costa Rica was examined: 532 individuals of different species of Pseudothelphusidae: Allacanthos pittieri (Rathbun, 1898), P. magnus, Ptychophallus barbillaensis Rodríguez \& Hedström, 2000, P. colombianus (Rathbun, 1893), P. paraxanthusi (Bott, 1968), P. tristani (Rathbun, 1896), P. tumimanus (Rathbun,
1898). However, no females carrying eggs or juveniles were encountered. The taxonomic identification of the material used for the present study was verified by one of us (CM).

The carapace width (CW: distance across the carapace at its widest point) and carapace length (CL: distance along the midline, from the frontal to the posterior margin) were measured for all females using a Vernier caliper (to nearest 0.05 $\mathrm{mm}$ ). The same measurements (using a stereomicroscope, to nearest $0.01 \mathrm{~mm}$ ) were obtained from the juveniles $(\mathrm{N}=10$ per female) attached to the females. Regarding ovigerous females, the entire egg mass was detached and counted. Subsequently, 20 eggs were arbitrarily separated from each female and measured the width and length of each egg under a microscope equipped with a calibrated ocular micrometer. These data were used to calculate egg volume (EV) according to the formula proposed by TuRnER \& LAWRENCE (1979) for oblate spheroids: EV $=1 / 6\left(a^{*} b^{2}{ }^{*} \pi\right)$, where ' $a$ ' represents length, and ' $b$ ' width. The developing embryos were classified in early (Stage I: embryos with uniform yolk) and advanced stages (Stage III: eyes clearly visible), following the criteria proposed by WeHRTMANN (1990). In accordance with similar studies of other brachyuran crabs (e.g. Hines 1991, Reid \& Corey 1991, Mantelatto \& Fransozo 1997, Pinheiro \& HatTori 2006), the relation between fecundity and female size was described by an allometric model (HuXLeY $1950 ; \mathrm{Y}=\mathrm{aX}{ }^{\mathrm{b}}$ ). In order to evaluate the possible mortality during embryogenesis and subsequent early juvenile development, an analysis of covariance (ANCOVA; ZAR 1999) was applied to examine the relation between offspring number (embryos and juveniles) and CW. In the case of a significant difference ( $\mathrm{p}<$ 0.05 ), the Tukey a posteriori test was used to establish the similarity between early developmental stages (ZAR 1999). Differences between the average of both egg diameter and egg volume of early (Stage I) and advanced eggs (Stage III) were tested using a Student t-test $(\mathrm{p}<0.05)$.

\section{RESULTS}

\section{Offspring production}

The only female of $P$. magnus examined herein measured $85.7 \mathrm{~mm} \mathrm{CW}$, and carried 179 juveniles with an average CW of $5.2 \pm 0.16 \mathrm{~mm}$ (Tab. I).

We examined a total of 20 females of K. latifrons: eight with eggs, two with attached juveniles, and 10 without eggs or hatchlings. In the case of K. ytupora, a total of 31 females were examined: eight carried eggs, 13 females with juveniles, and 10 females without eggs or juveniles. A regression analysis of the relationship between number of eggs and crab body size showed that fecundity increased with female size of $K$. ytupora (Fig. 1). Most females with or without eggs/hatchlings were in the size range between $40-50 \mathrm{~mm} \mathrm{CW}(85 \%$; K. latifrons) and 45-55 mm CW (58\%; K. ytupora).

Mean size of female $K$. latifrons $(45.4 \pm 3.03 \mathrm{~mm} \mathrm{CW})$ and $K$. ytupora $(49.8 \pm 4.52 \mathrm{~mm} \mathrm{CW})$ carrying eggs or juveniles 
was significantly different (Student t-test; $\mathrm{t}=3.05 ; \mathrm{p}<0.001$ ) (Tab. I). The mean egg number was higher in K. ytupora (80 \pm 18.1 eggs) than in K. latifrons (73 \pm 10.6 eggs) (Tab. I). Recentlyproduced eggs were significantly larger (Student $\mathrm{t}$-test, $\mathrm{t}=7.33$; $\mathrm{p}<0.001$ ) in $K$. latifrons (mean egg length $2.83 \pm 0.136 \mathrm{~mm}$ ) when compared to those of $K$. ytupora (mean egg length $1.87 \pm$ $0.093 \mathrm{~mm}$ ); however, at the end of the embryogenesis (Stage III), mean egg diameter was similar in both species (Tab. I). Likewise, the mean egg volume of freshly-extruded eggs was significantly larger (Student t-test, $\mathrm{t}=7.33$; $\mathrm{p}<0.001$ ) in $K$. latifrons $\left(10.8 \pm 1.74 \mathrm{~mm}^{3}\right)$ than in K. ytupora $\left(3.2 \pm 0.52 \mathrm{~mm}^{3}\right)$. Eggs close to hatching (Stage III), however, reached a larger mean egg volume $\left(21.0 \pm 2.37 \mathrm{~mm}^{3}\right)$ in $K$. ytupora compared to that of the single female of $K$. latifrons carrying eggs in Stage III $\left(19.9 \mathrm{~mm}^{3}\right)$ (Tab. I). We did not detect statistically significant differences between the slopes of eggs/attached juveniles versus CW in K. ytupora (Fig. 1).

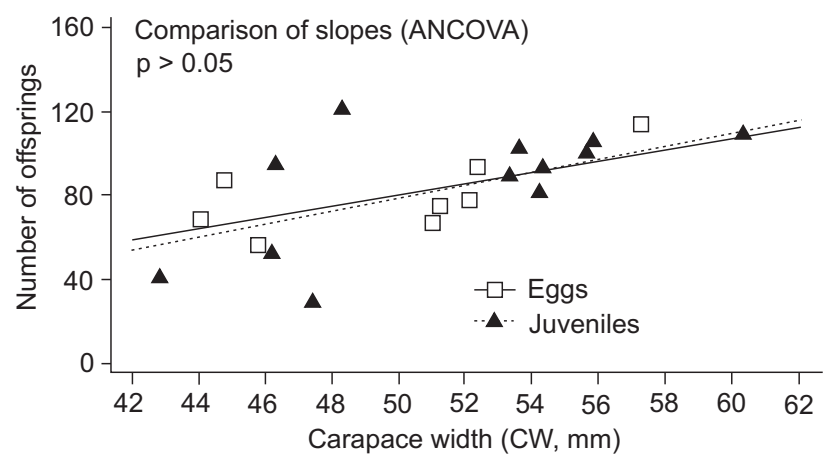

Figure 1. Number of eggs and attached juveniles in the freshwater crab Kingsleya ytupora from the Amazon region (Brazil), with a comparison of slopes (ANCOVA).

The mean size of the juveniles from the two female $K$. latifrons was $4.92 \pm 0.390 \mathrm{~mm} \mathrm{CW}$. In the case of $K$. ytupora, two cohorts of juveniles were detected (Fig. 2): the early juveniles measured on average $4.30 \mathrm{~mm} \mathrm{CW}$, the larger ones 4.93 $\mathrm{mm} \mathrm{CW}$, which represents an size increment of $15 \%$.

\section{Juveniles of $K$. ytupora}

The first juvenile stage has a swollen, orbicular carapace, with smooth lateral margins; exorbital angle rounded; frontal margin narrow, smooth, with a very shallow notch in the middle, distinctly projected anteriorly, partially covering the eyestalks; spots of yolk supply visible through the thin carapace (Figs 3 and 4). The second juvenile stage has a dorsally flat carapace, a little broader than in the first stage, lateral margins with rudimentary spines, a bit larger anteriorly; exorbital angle with a small acute spine; frontal margin clearly bilobed, slightly rugose and projected anteriorly, with a deep median notch.

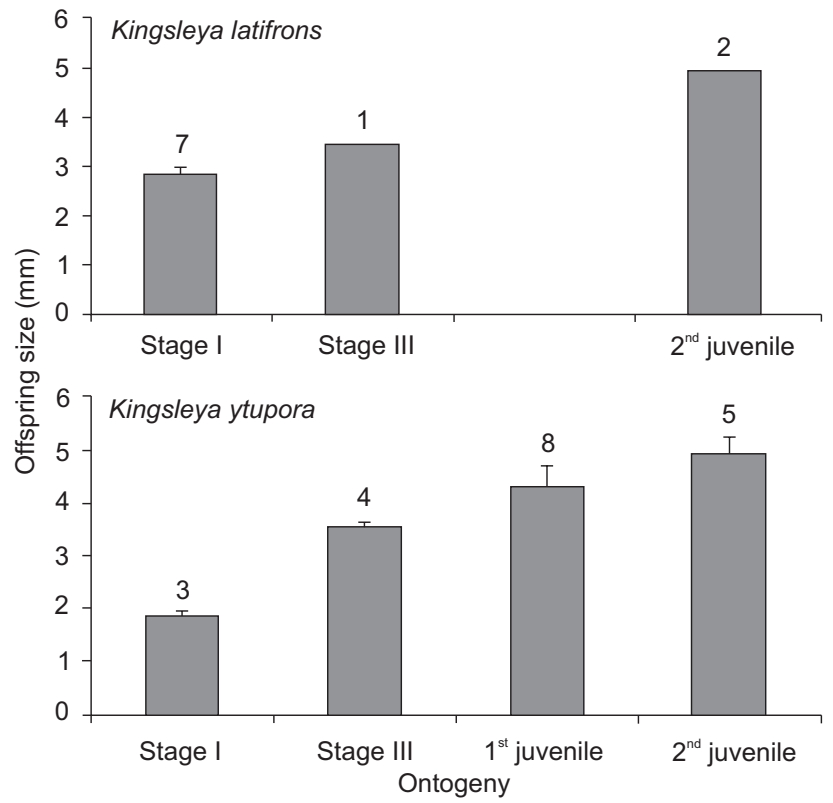

Figure 2. Offspring size (egg length and carapace width of attached juveniles) during the early development of the freshwater crabs Kingsleya latifrons (top) and K. ytupora (bottom).

\section{DISCUSSION}

With the exception of the knowledge about the fecundity of the trichodactylid crabs Dilocarcinus pagei Stimpson, 1861 and Sylviocarcinus australis Magalhães \& Türkay, 1996 (see Mansur \& Hebling 2002), the results here obtained by us represent the first detailed report on egg production and presence of juveniles associated with female pseudothelphusid crabs inhabiting the Neotropics. The findings of our investigation are based upon a relatively low number of observations per species when compared to other studies on the egg production of abundant marine brachyuran decapods (e.g. Hines 1991, REID \& Corey 1991, Mantelatto \& Fransozo 1997, Litulo et al. 2005). The obvious lack of information about reproductive features of neotropical freshwater crabs may be explained by 1) the cryptic habit of these crabs (MAGALHÃES 1986), specially ovigerous females and females bearing juveniles; 2 ) their nocturnal habit (MAGALHÃES 1986, 2003a); 3) their habitat covers mostly remote areas which results in sporadic collections, thus limiting the possibility to adequately describe the complete life cycle of these freshwater crabs (MAGALHÃES 1986, 2003a); and 4) the relatively low number of specialists working on the biology/ecology of this group in the Americas. Both the absence of published information on female reproduction and the low number of females with eggs or juveniles in the collections analyzed by us suggest that those females are even more difficult to collect than males or females without eggs. In accordance with this conclusion, Mansur \& Hebling (2002), studying the reproduc- 


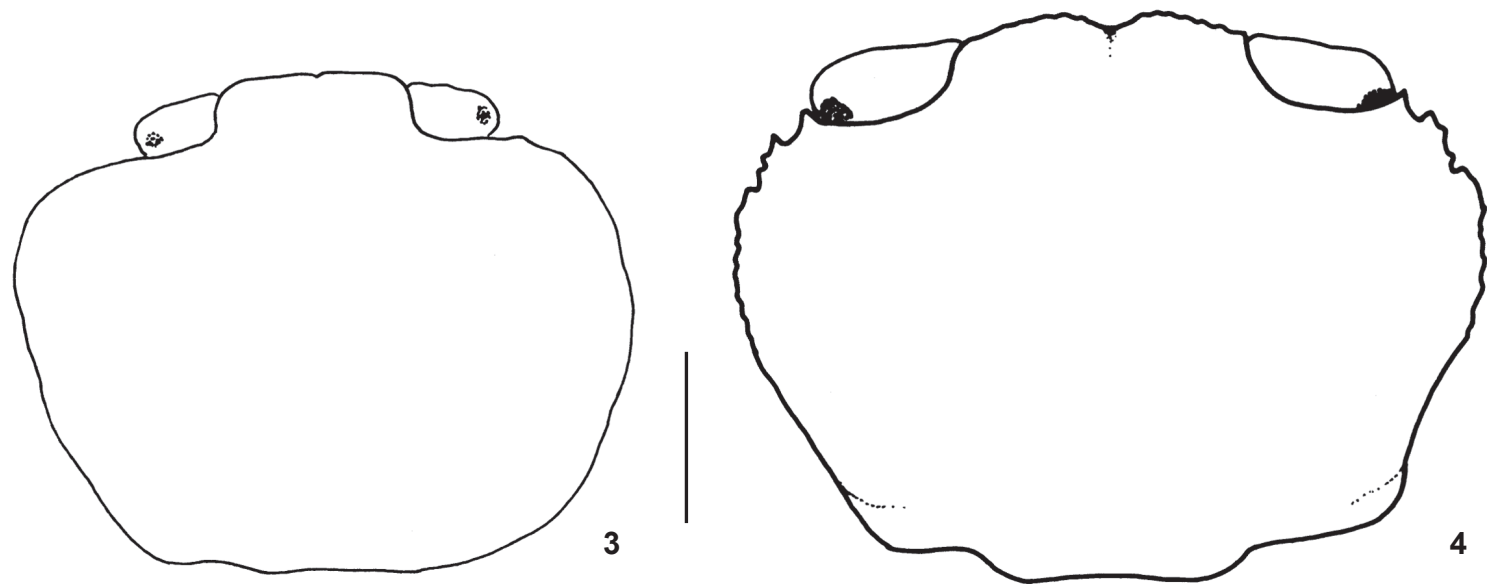

Figures 3-4. Kingsleya ytupora: dorsal view of carapace of first (3) and second juveniles (4) encountered on the abdomen of females. Scale bar: $1 \mathrm{~mm}$.

tion of two crabs of the family Trichodactylidae, also mentioned the difficulty to collect females with eggs or juveniles. Likewise, Disney (1971) emphasized the scarcity of females bearing eggs or young and argued that they may retract into their burrows and forage less at this time. Our long-lasting experience in field collections of these decapods in the Neotropics corroborates the above-mentioned conclusions.

All three crab species studied herein produced relatively few but large eggs (Tab. I), typical for species with an abbreviated or direct development (McEDWARD 1997). To the best of our knowledge, the only published information on fecundity in neotropical freshwater crabs is of Dilocarcinus pagei and Silviocarcinus australis (Trichodactylidae) from Brazil (MANsur \& HeBLING 2002): these crab species produced on average slightly more eggs (214 and 170, respectively; Tab. I) than the two Kingsleya species studied herein. MagalHÃEs (1986) reported that two females of $K$. latifrons from rio Uatumã (Amazonas) carried 57 and 67 eggs, which is within the range found in the present study.

Table I summarizes the available information about reproductive features of freshwater crabs. These data about egg production suggest that freshwater crabs produce on average between 100 and 300 eggs; however, fecundity may vary greatly intra- and interspecifically (COREy \& ReID 1991).

Exact data on the egg size of freshwater crabs are rare. All available information indicates that the egg diameter of these crabs is in the range of 2 and $3 \mathrm{~mm}$, independent of female size and fecundity (Tab. I). However, most studies did not consider the developmental stage of the eggs, which impedes a comparison of the published values: egg size in decapods tends to increase during the incubation period (WEHRTMAnN \& KattNer 1998, Yamaguchi 2001, Wehrtmann \& López 2003, Pavanelli et al. 2008), and this increase is typically related to the incorporation of large amounts of water (PANDiAn 1970). In contrast,
Mansur \& Hebling (2002) mentioned that the egg diameter of $D$. pagei and $S$. australis did not vary during embryogenesis. The present results, although based on only few observations of eggs in different developmental stages, indicate a substantial increase of both egg diameter and egg volume (Tab. I). In the case of K. latifrons and K. ytupora, the egg diameters encountered during the end of the embryogenesis represent the highest values so far reported for freshwater crabs, but additional data of the egg size variation during the incubation period from other species are needed for a valid comparison.

Egg volume is a widely used parameter to describe and compare reproductive traits among decapods (e.g. COREY \& REID 1991, Киво et al. 2006, Terossi et al. 2010), including brachyuran crabs (Reid \& Corey 1991, Navarette et al. 1999). The first egg volume data for freshwater crabs is presented here (Tab. I). Despite the fact that the mean egg volume of freshly-extruded eggs of $K$. latifrons was more than three times larger than in K. ytupora, our data indicated that eggs close to hatching were larger in $K$. ytupora (Tab. I). This surprising result needs to be substantiated by additional egg data for both species, especially for K. latifrons where we obtained only one female with eggs in Stage III. Notwithstanding, these results may indicate that (a) K. latifrons invests more energy in the initial egg production than $K$. ytupora, and (b) eggs of $K$. ytupora increase during the incubation period considerably more in volume than those of $K$. latifrons. These hypotheses might be tested by future laboratory rearing experiments studying the entire incubation period of both species.

Egg mortality during embryogenesis is a common phenomenon in decapods (see KuRIS 1991 for review). In the case of $K$. ytupora, the present results (Fig. 1) indicate that this species is not suffering a substantial loss of eggs or juveniles. We assume that parental care diminishes the loss of eggs and juveniles. Such behavior is often highly developed in species inhabiting extreme environments and species which produce only 
Table I. Comparison of reproductive features in freshwater crabs (n.a. = information not indicated in the cited publication; $\mathrm{CL}=\mathrm{carapace}$ length; $\mathrm{CW}=$ carapace width). Egg size (egg length or egg diameter, otherwise not specified in the study) refers to eggs independent of their developmental stage.

\begin{tabular}{|c|c|c|c|c|c|}
\hline Species & $\begin{array}{l}\text { Size of ovigerous } \\
\text { females }(\mathrm{mm})\end{array}$ & Number of eggs & $\begin{array}{l}\text { Number of } \\
\text { hatchlings }\end{array}$ & Egg size (mm) & $\begin{array}{l}\text { Size of hatchlings } \\
(\mathrm{mm} \mathrm{CW})\end{array}$ \\
\hline Candidopotamon rathbunae & $22.3-36.8 \mathrm{CW}$ & $9-117$ & n.a. & 2.96 & n.a. \\
\hline Dilocarcinus pagei & $43.49 \mathrm{CL}$ & n.a. & $298.4(12-1071)$ & n.a. & n.a. \\
\hline Dilocarcinus pagei & $32-34$ to $50-52 \mathrm{CL}$ & $213.8(120-299)$ & 83-1057 & Egg diameter 2.0 & n.a. \\
\hline Rodriguezus garmani (Rathbun) & n.a. & $\sim 200-300$ & n.a. & Egg diameter $\sim 2-3$ & n.a. \\
\hline Geothelphusa exigua Suzuki \& Tsuda & $18.6-26.6 \mathrm{CW}$ & 17 & 42 & n.a. & $4.1 \pm 0.17$ \\
\hline Geothelphusa dehaani (White) & $17.8-31.6 \mathrm{CW}$ & n.a & n.a & n.a. & $4.5+0.28$ \\
\hline Kingsleya latifrons & $41.9-51.0 \mathrm{CW}$ & $73 \pm 10.6(65-85)$ & 61 & Egg length $2.7-3.4(2.98 \pm 0.321)$ & $3.9 \pm 0.28(3.4-4.2)$ \\
\hline Kingsleya ytupora & $42.8-60.3 \mathrm{CW}$ & $80 \pm 18.1(56-114)$ & $30-122$ & Egg length 1.8-3.7 $(2.90 \pm 0.860)$ & $4.5 \pm 0.48(3.8-5.2)$ \\
\hline Spiralothelphusa hydrodroma (Herbst) & n.a. & $289.76-333.0$ & $142.4-147.7$ & Egg diameter $2.20+0.45$ & n.a. \\
\hline Spiralothelphusa hydrodroma & $3.1-5.5 \mathrm{CW}$ & $247-417$ & n.a. & n.a. & n.a. \\
\hline Potamon fluviatile (Herbst) & $41.99+0.28 \mathrm{CL}$ & $103.7(55-157)$ & n.a. & n.a. & n.a. \\
\hline Potamocarcinus magnus & $85.7 \mathrm{CW}$ & n.a. & 179 & n.a. & $5.2 \pm 0.16(5.0-5.4)^{* *}$ \\
\hline $\begin{array}{l}\text { Potamon fluviatile lanfrancoi } \\
\text { Capolongo \& Cilia }\end{array}$ & n.a. & $\sim 200$ & n.a. & $\sim 2.5$ & $\sim 3.5$ \\
\hline Sinopotamon yangtsekiense Bott & $18-35 \mathrm{CL}$ & $30-100$ & n.a. & n.a. & $\sim 4$ \\
\hline Sylviocarcinus australis & $20-22$ to $42-44 \mathrm{CL}$ & $170.2(57-200)$ & $78.3-442.0$ & Egg diameter 2.0 & n.a. \\
\hline \multirow[t]{2}{*}{ Species } & \multicolumn{2}{|c|}{$\begin{array}{l}\text { Mean egg volume } \pm \text { SD } \mathrm{mm}^{3} \text { (max. } \\
\text { egg diameter in } \mathrm{mm})\end{array}$} & \multirow[t]{2}{*}{ Duration of incubation period } & \multirow{2}{*}{\multicolumn{2}{|c|}{ Reference and country }} \\
\hline & Early stage & Advanced stage & & & \\
\hline Candidopotamon rathbunae & n.a. & n.a. & 45 days & \multicolumn{2}{|c|}{ LIU \& LI (2000), Taiwan, China } \\
\hline Dilocarcinus pagei & n.a. & n.a. & n.a. & \multicolumn{2}{|c|}{ Davanso et al. (2007), Brazil } \\
\hline Dilocarcinus pagei & n.a. & n.a. & n.a. & \multicolumn{2}{|c|}{ Mansur \& Hebling (2002), Brazil } \\
\hline Rodriguezus garmani (Rathbun) & n.a. & n.a. & \multicolumn{3}{|c|}{$\begin{array}{l}\text { Rostant et al. (2008), Trinidad, West } \\
\text { Indies }\end{array}$} \\
\hline Geothelphusa exigua Suzuki \& Tsuda & n.a. & n.a. & \multicolumn{3}{|c|}{ OKANo et al. (2000), Japan } \\
\hline Geothelphusa dehaani (White) & n.a. & n.a. & \multicolumn{3}{|c|}{ OKANo et al. (2000), Japan } \\
\hline Kingsleya latifrons & $10.8 \pm 1.74(2.92)$ & $19.9(3.43)^{*}$ & \multicolumn{3}{|c|}{ Present study, Brazil } \\
\hline Kingsleya ytupora & $3.2 \pm 0.52(1.94)$ & $21.0 \pm 2.37(3.46)$ & \multicolumn{3}{|c|}{ Present study, Brazil } \\
\hline Spiralothelphusa hydrodroma (Herbst) & n.a. & n.a. & \multicolumn{3}{|c|}{ Pillai \& Subramoniam (1985), India } \\
\hline Spiralothelphusa hydrodroma & n.a. & n.a. & \multicolumn{3}{|c|}{ PILlai \& Subramoniam (1984), India } \\
\hline Potamon fluviatile (Herbst) & n.a. & n.a. & \multicolumn{3}{|c|}{ MıснеLI et al. (1990), Italy } \\
\hline Potamocarcinus magnus & n.a. & n.a. & \multicolumn{3}{|c|}{ Present study, Costa Rica } \\
\hline $\begin{array}{l}\text { Potamon fluviatile lanfrancoi } \\
\text { Capolongo \& Cilia }\end{array}$ & n.a. & n.a. & \multicolumn{3}{|c|}{$\begin{array}{c}\text { CAPOLOnGo \& Cilla (1990), Republic of } \\
\text { Malta }\end{array}$} \\
\hline Sinopotamon yangtsekiense Bott & n.a. & n.a. & \multicolumn{3}{|c|}{ CHEN et al. (1994), China } \\
\hline Sylviocarcinus australis & n.a. & n.a. & \multicolumn{3}{|c|}{ Mansur \& Hebling (2002), Brazil } \\
\hline
\end{tabular}

* Data from one single female; ** data from one single female with juveniles. 
a limited number of offspring (THIEL 2003). According to this author, extended parental care has been reported so far in 35 brachyuran crabs. Since the present study is based on preserved specimens, we do not have live observations about (possible) parental care behavior in these species. However, these relative large freshwater crabs should be an ideal object to study such behavior under laboratory conditions.

As observed and described for other freshwater crabs (see references cited in Tab. I), individuals attached to the females of the three species studied herein were juveniles. Although we did not observe the hatching process, it is assumed that all three species display a direct development, as this is a common feature for all of the so-called primary freshwater crabs (Yeo et al. 2008, Cumberlidge \& Ng 2009).

The presence of juveniles attached to the female has been already reported for several freshwater crabs (see Tab. I). Our results for K. ytupora (Fig. 2) clearly show that two size groups can be found on the abdomen of the females. Considering that the egg size at the end of the incubation period was almost identical in both Kingsleya species (Tab. I), it seems safe to assume that the hatchlings in both species should have a similar size (e.g. Shirley et al. 1987, Wehrtmann \& Albornoz 2003, WEHRTMANN \& López 2003). Therefore, we firmly believe that juveniles of $K$. latifrons hatch at a similar size as those in $K$. ytupora. However, the limited number of females of $K$. latifrons with juveniles simply did not allow encountering females carrying the smaller size group of juveniles.

The presence of two size groups seems to indicate that juveniles are attached to the mother for a prolonged time period. In the case of Candidiopotamon rathbunae (De Man, 1914), brooding females carry their juveniles between 9 and 16 days (Liu \& Li 2000). According to these authors, the post-hatching period seems to be correlated with the calcification of the cuticle of juvenile crabs. Similarly, juveniles of Aegla perobae Hebling \& Rodrigues, 1977 remain attached to the abdomen of the female for 8-12 days after hatching (Rodriguez \& HebLing 1978). In A. castro Schmitt, 1942 this period extends until 15 days (Swiech-Ayoub \& Masunari 2001), while in A. uruguayana Schmitt, 1942 and A. platensis Schmitt, 1942 females carried their young for 3-4 and 10 days, respectively (López-Greco et al. 2004, Lizardo-Daudt \& Bond-Buckup 2003). In contrast, Parathelphusa hydrodomous (Herbst) seems to carry their young for a substantially longer period of time. According to Pillai \& Subramoniam (1984), the average number of days spent by the juveniles in the brood was 63.7 days with marked interannual variation, varying between 38 and 100 days. In the case of the three freshwater crab species studied herein, the exact duration of the attachment of the offspring to the mother cannot be established by our data, and future laboratory studies are needed to clarify this aspect.

The description of the carapace (Figs 3 and 4 ) allows morphologically distinguishing of the two size groups of attached juveniles in K. ytupora. These results coincide with the fact that roughly $70 \%$ of the 28 crustacean species so far reported to have attached offspring, carry them until they reach the second juvenile stage (Thiel 2003). At least in Cherax cainii Austin, 2002 the first two stages of juveniles have recurved spines on the dactyls of their fourth and fifth pereopods, which facilitate their attachment to the mother; the third juvenile stage is independent of the mother, and their dactyl spines are straight and cannot grasp the mother's pleopods (BURTON et al. 2007). We did not detect such recurved spines in the attached juveniles of the crab species studied herein. However, a more detailed study of the morphological and behavioral adaptations of the different juvenile stages is recommended in order to better describe the mechanism which hatchlings use to remain attached to their mothers in fast-flowing habitats.

\section{ACKNOWLEDGEMENTS}

This study forms part of a bilateral research program coordinated by FLM and ISW, and was financially supported by CNPq - Brazil (Proc. 491490/2004-6 and 490353/2007-0), CONICIT - Costa Rica (CII-001-08), and the Universidad de Costa Rica (VI 808-A8-209). We appreciate the collaboration of Helena del Barrio Alvarellos (Centre d'Estudis Avançats de Blanes, Spain) who kindly helped us locating difficult to obtain publications, Sergio Bueno (IB/USP) who furnished some literature and information on aeglids, and anonymous reviewers for their valuable suggestions. All experiments conducted in this study complied with current applicable state and federal laws of Brazil (DIFAP/IBAMA). CM and FLM thank CNPqBrazil for an ongoing research grant, and CAPES/DAAD (Proc. 315-09) for partial support during this project. PH is grateful for ongoing PhD fellowship from CAPES-Brazil. The first author (ISW) is also affiliated to the Museo de Zoología and the Escuela de Biología, both of the Universidad de Costa Rica.

\section{LITERATURE CITED}

Burton, T.; B. Knott; D. Judge; P. Vercoe \& A. Brearley. 2007. Embryonic and juvenile attachment structures in Cherax cainii (Decapoda: Parastacidae): implications for maternal care. American Midland Naturalist 157: 127-136.

Capolongo, D. \& J.L. Cilia. 1990. Potamon fluviatile lanfrancoi, a new subspecies of a Mediterranean freshwater crab from the Maltese Islands (Crustacea, Decapoda, Potamidae). Annalen des Naturhistorischen Museums Wien 91 B: 215-224.

Chen, T.; W. LaI \& N.-S. Du. 1994. Growth, reproduction and population structure of the freshwater crab Sinopotamon yangtsekiense Bott, 1967, from Zhejiang, China. Chinese Journal of Oceanology and Limnology 12: 84-90.

Corey, S. \& D.M. ReID. 1991. Comparative fecundity of decapod crustaceans. I. The fecundity of thirty-three species of nine families of caridean shrimp. Crustaceana 60: 270-294.

Cumberlidge, N. \& P.K.L. Ng. 2009. Systematics, evolution, and 
biogeography of freshwater crabs, p. 491-508. In.: J.W. Martin, K.A. Crandall \& D.L. Felder (Eds). Crustacean Issues: Decapod Crustacean Phylogenetics. Boca Raton,Francis and Taylor/CRC Press.

Davanso, T.M.; M.F. Darim; F.S. David \& F.G. TadDei. 2007. Número de filhotes em Dilocarcinus pagei Stimpson, 1861 (Decapoda: Brachyura: Trichodactylidae) da represa de Furnas/ Marimbondo, ICÉM, SP, p. 1-2. In: Anais do VIII Congresso de Ecologia do Brasil. Available online at: http://www.sebecologia.org.br/viiiceb/trabalhos.html [Accessed: 27.XI.2010].

Disney, R.H.L. 1971. Notes on Simulium ovazzae Grenier and Mouchet (Diptera: Simuliidae) and river crabs (Malacostraca: Potamidae) and their association. Journal of Natural History 5: 677-689.

Hines, A.H. 1991. Fecundity and reproductive output in nine species of Cancer crabs (Crustacea, Brachyura, Cancridae). Canadian Journal of Fisheries and Aquatic Sciences 48: 267-275.

HuXley, J.S. 1950. Relative growth and transformation. Proceedings of the Royal Society of London. Series B: Biological Sciences 137: 465-469.

Kubo, K.; K. Shimoda \& A. Tamaki. 2006. Egg size and clutch size in three species of Nihonotrypaea (Decapoda: Thalassinidea: Callianassidae) from western Kyushu, Japan. Journal of the Marine Biological Association of United Kingdom 86: 103-111.

KuRIS, A. 1991. A review of patterns and causes of crustacean broad mortality, p. 117-141. In: A.M. WENNER \& A. KURIS (Eds). Egg production in crustacean. Rotterdam, Balkema, Crustacean Issues, vol. 7.

Litulo, C.; A. Macia \& F.L. Mantelatto. 2005. Fecundity and sexual maturity of the crab Macrophthalmus depressus (Brachyura: Ocypodidae) from Inhaca Island, Mozambique. African Journal of Aquatic Science 30: 179-183.

Liv, H.C. \& C.W. Li. 2000. Reproduction in the fresh-water crab Candidiopotamon rathbunae (Brachyura: Potamidae) in Taiwan. Journal of Crustacean Biology 20: 89-99.

Lizardo-Daudt, H.M. \& G. Bond-Buckup. 2003. Morphological aspects of the embryonic development of Aegla platensis (Decapoda, Aeglidae). Crustaceana 76: 13-25.

López Greco, L.S.; V. Viau; M. Lavolpe; G. Bond-Buckup \& E.M. RoDriguez. 2004. Juvenile hatching and maternal care in Aegla uruguayana (Anomura, Aeglidae). Journal of Crustacean Biology 24: 309-313.

MAGALHãES, C. 1986. Revisão taxonômica dos caranguejos de água doce brasileiros da família Pseudothelphusidae (Crustacea, Decapoda). Amazoniana 9: 609-636.

Magalhães, C. 2003a. Famílias Pseudothelphusidae e Trichodactylidae, p. 143-287. In: G.A.S. Melo (Ed.). Manual de identificação dos Crustacea Decapoda de água doce do Brasil. São Paulo, Editora Loyola.

Magalhães, C. 2003b. The occurrence of freshwater crabs (Crustacea: Decapoda: Pseudothelphusidae, Trichodactylidae) in the Rio Xingu, Amazon Region, Brazil, with description of a new species of Pseudothelphusidae. Amazoniana 17: 377-386.

Magalhães, C. \& M. TÜrkay. 2008. A new species of Kingsleya from the Yanomami Indians area in the Upper Rio Orinoco, Venezuela (Crustacea: Decapoda: Brachyura: Pseudothelphusidae). Senckenbergiana Biologica 88: 1-7.

Mansur, C.B. \& N.S. Hebling. 2002. Análise comparativa entre a fecundidade de Dilocarcinus pagei Stimpson e Sylviocarcinus australis Magalhães \& Türkay (Crustacea, Decapoda, Trichodactylidae) no Pantanal do Rio Paraguai, Porto Murtinho, Mato Groso do Sul. Revista Brasileira de Zoologia 19 (3): 797-805. doi: 10.1590/S0101-817520020003000 18.

Mantelatto, F.L. \& A. Franzoso. 1997. Fecundity of the crab Callinectes ornatus Ordway, 1863 (Decapoda, Brachyura, Portunidae) from Ubatuba region, São Paulo, Brazil. Crustaceana 70: 214-226.

McEDWARD, L.R. 1997. Reproductive strategies of marine benthic invertebrates revisited: facultative feeding by planktotrophic larvae. American Naturalist 150: 48-72.

Micheli, F.; F. Gherardi \& M. Vannini. 1990. Growth and reproduction in the freshwater crab, Potamon fluviatile (Decapoda, Brachyura). Freshwater Biology 23: 491-503.

Navarette, N.; R. Soto; E. Quiroga; M. Vargas \& I.S. Wehrtmann. 1999. Egg production in Eurypodius latreilleii Guérin, 1828, (Decapoda: Majidae) in the Straits of Magellan, southern Chile. Scientia Marina 63 (Suppl. 1): 333-337.

NG, P.K.L.; D. GuINot \& P.J.F. DAvie. 2008. Systema Brachyurorum: Part I. An annotated checklist of extant brachyuran crabs of the world. The Raffles Bulletin of Zoology Supplement 17: 1-286.

Okano, T.; H. Suyuku \& T. Miura. 2000. Comparative biology of two Japanese freshwater crabs Geothelphusa exigua and $G$. dehaani (Decapoda, Brachyura, Potamidae). Journal of Crustacean Biology 20: 299-308.

Pandian, T.J. 1970. Ecophysiological studies on the developing eggs and embryos of the European lobster Homarus gammarus. Marine Biology 5: 154-167.

Pavanelli, C.A.M.; C.E. Mossolin \& F.L. Mantelatto. 2008. Reproductive strategy of the snapping shrimp Alpheus armillatus H. Milne-Edwards, 1837 in the South Atlantic: fecundity, egg features, and reproductive output. Invertebrate Reproduction and Development 52: 123-130.

Pillai, C.K. \& T. Subramoniam. 1984. Monsoon-dependent breeding in the field crab Parathelphusa hydrodromous (Herbst). Hydrobiologia 119: 7-14.

Pillai, C.K. \& T. Subramoniam. 1985. Yolk utilization as an adaptive strategy of terrestrialization in the freshwater crab Parathelphusa hydrodromous (Herbst). Physiological Zoology 58: 445-457.

Pinheiro, M.A.A. \& G. Hattori. 2006. Relative growth of the mangrove crab Ucides cordatus (Linnaeus, 1763) (Crustacea, Brachyura, Ocypodidae) at Iguape, São Paulo, Brazil. Brazilian Archives of Biology and Technology 49: 813-823. 
ReID, D. \& S. Corey. 1991. Comparative fecundity of decapod crustaceans II. The fecundity of fifteen species of anomuran and brachyuran crabs. Crustaceana 61: 175-189.

Rodrigues, W. \& N.J. Hebling. 1978. Estudios biólogicos em Aegla perobae Hebling \& Rodriguez, 1977 (Decapoda, Anomura). Revista Brasileira de Biologia 38: 383-390.

Rodríguez, G. 1982. Fresh-water shrimps (Crustacea, Decapoda, Natantia) of the Orinoco basin and the Venezuelan Guayana. Journal of Crustacean Biology 2: 378-391.

RodrígueZ, G. \& C. MagalHÃEs. 2005. Recent advances in the biology of the neotropical freshwater crab family Pseudothelphusidae (Crustacea: Decapoda: Brachyura). Revista Brasileira de Zoologia 22 (2): 354-365. doi: 10.1590/S0101-81752005000200009

Rostant, L.V.; M. Alkins-Koo \& D.P. Maitland. 2008. Growth and maturity in the manicou crab Eudaniela garmani (Brachyura: Pseudothelphusidae) from Trinidad, West Indies. Journal of Crustacean Biology 28: 485-493.

SHIRLEy, S.M.; T.C. Shirley \& S.D. Rice. 1987. Latitudinal variation in the Dungeness crab, Cancer magister: zoeal morphology explained by incubation temperature. Marine Biology 95: 371-376.

Swiech-Ayoub, B. P. \& S. Masunari. 2001. Biologia reprodutiva de Aegla castro Schmitt (Crustacea, Anomura, Aeglidae) no Buraco do Padre, Ponta Grossa, Paraná, Brasil. Revista Brasiliera de Zoologia 18 (3): 1019-1030. doi: 10.1590/ S0101-81752001000300033.

Terossi, M.; I.S. Wehrtmann \& F.L. Mantelatto. 2010. Interpopulational comparison of reproduction of the Atlantic shrimp Hippolyte obliquimanus Dana, 1852 (Caridea: Hippolytidae). Journal of Crustacean Biology 30: 571-579.

Thiel, M. 2003. Extended parental care in crustaceans - an update. Revista Chilena de Historia Natural 76: 205-218.
Turner, R.L. \& J.M. LAWRENCE. 1979. Volume and composition of echinoderm eggs: implications for the use of egg size in lifehistory models, p. 25-40. In: W.E. STANCYK (Ed.). Reproductive ecology of marine invertebrates. Columbia S.C., University South Carolina Press, Belle W. Baruch Library in Marine Science, vol. 9.

WeHRTMAnn, I.S. 1990. Notes on the distribution and reproduction of Ambidexter panamense and Palaemonetes schmitti in Pacific Costa Rica (Crustacea, Decapoda). Revista de Biología Tropical 38: 327-329.

Wehrtmann, I.S. \& L. Albornoz. 2003. Larvae of Nauticaris magellanica (Decapoda: Caridea: Hippolytidae) reared in the laboratory differ morphologically from those in nature. Journal of the Marine Biological Association of United Kingdom 83: 949-957.

WEHRTMANN, I.S. \& G. KatTNER. 1998. Changes in volume, biomass, and fatty acids of developing eggs in Nauticaris magellanica (Decapoda: Caridea): a latitudinal comparison. Journal of Crustacean Biology 18: 413-422.

Wehrtmann, I.S. \& G.A. López. 2003. Effects of temperature on the embryonic development and hatchling size of Betaeus emarginatus (Decapoda: Caridea: Alpheidae). Journal of Natural History 37: 2165-2178.

YAMAGUCHI, T. 2001. Incubation of eggs and embryonic development of the fiddler crab Uca lactea (Decapoda, Brachyura, Ocypodidae). Crustaceana 74: 449-458.

Yeo, D.C.J.; P.K.L. Ng; N. Cumberlidge; C. Magalhães; S.R. Daniels \& M.R. CAmpos. 2008. Global diversity of crabs (Crustacea: Decapoda: Brachyura) in freshwater. Hydrobiologia 575: 275-286. doi: 10.1007/s10750-007-9023-3

ZAR, J.H. 1999. Biostatistical analysis. Upper Saddle River, Prentice Hall, 663p.

Submitted: 19.VIII.2010; Accepted: 15.XI.2010.

Editorial responsibility: Carolina Arruda Freire 
This article has received corrections asked by the editor on Fe/2011 in agreement with the ERRATUM published in Volume 28 Number 1.

(http://www.scielo.br/pdf/zool/v28n1/v28n1a22.pdf) 